\title{
Effect of Nanopowdered Peanut Sprouts on Physicochemical and Sensory Properties of Milk
}

\author{
Yu-Jin Ahn, Palanivel Ganesan, and Hae-Soo Kwak* \\ Department of Food Science and Technology, Sejong University, Seoul 143-747, Korea
}

\begin{abstract}
A study was conducted to examine the physicochemical and sensory properties of milk supplemented with nanopowdered peanut sprouts (NPPS) at different concentrations $(1,3,5,7$, and $9 \%, \mathrm{w} / \mathrm{v})$ during the storage at $4^{\circ} \mathrm{C}$ for $16 \mathrm{~d}$. The size of NPPS ranged from $300-350 \mathrm{~nm}$ as observed by the particle size analyzer. The $\mathrm{pH}$ values of all samples ranged from 6.8 to 6.6 during the storage of $16 \mathrm{~d}$. In color, the $\mathrm{L}^{*}$ value of milk samples were not remarkably influenced by NPPS supplementation, whereas the $\mathrm{b}^{*}$ and $\mathrm{a}^{*}$ values significantly increased with the NPPS supplementation at all concentrations at $0 \mathrm{~d}$ storage, due to the original yellow color of NPPS powder $(p<0.05)$. DPPH study revealed that higher antioxidant activity of milk supplement with higher concentrations of NPPS. TBARS value found to lower at the lower concentrations $(1$ and $3 \%$, w/v) of NPPS supplementation. The sensory test revealed that the overall acceptability scores of NPPS supplemented milk samples ( 1 and 3\%,w/v) were quite similar to control throughout the storage period of $16 \mathrm{~d}$. Based on the data obtained from the present study, it was concluded that the concentrations ( 1 and $3 \%, \mathrm{w} / \mathrm{v})$ of NPPS could be used to produce NPPS-supplemented milk without significant adverse effects on physicochemical and sensory properties, and enhance functional components from the supplementation.
\end{abstract}

Key words: milk, nanopowdered peanut sprout, antioxidant activity, sensory properties

\section{Introduction}

Polyphenols and its derivative compounds deserve a large interest since it is mainly associated with the prevention of various diseases, such as coronary heart disease and cancer (Servili et al., 2009). Hundreds of polyphenol are occur in edible plants which play a defense role in plants and also serve as antioxidative and anti-inflammatory properties in the dietary. Peanut sprouts are rich in naturally occurring phytoelaxtin, such as resveratrol with an average content of $110.05 \mu \mathrm{g} / \mathrm{g}$ (Kang et al., 2010). Other sources contains resveratrol, but at much lower level such as cranberry juice $(0.24 \mu \mathrm{g} / \mathrm{g})$, strawberry $(0.11$ $\mu \mathrm{g} / \mathrm{g})$, blueberry $(0.02-0.03 \mu \mathrm{g} / \mathrm{g})$, and peanuts $(0.01-1.79$ $\mu \mathrm{g} / \mathrm{g}$ ) (Lyons et al., 2003; Tokusoglu et al., 2005; Wang et al., 2002). As the consequence, this peanut sprout extract represents an alternative source of bioactive compounds used to fortify functional foods and/or beverages. Further it has been shown to prevent various disease, such as

*Corresponding author: Hae-Soo Kwak, Department of Food Science and Technology, Sejong University, Seoul 143-747, Korea. Tel: 82-2-3408-3226, Fax: 82-2-3408-4319, E-mail: kwakhs@sejong.ac.kr
Alzheimer's, cancer, and cardiovascular, and proven to extend the life span of various organisms. Recent data also suggested that it has a beneficial role in diabetic prevention and reducing some of its complications. Further it reduced the oxidative stress and renal dysfunction in diabetic rats (Sharma et al., 2006).

Nano sizing is a recent emerging technique which is used in foods to enhance the stability and functional properties of food product (Park et al., 2007). According to Seo et al. (2011), ascorbic acid solubilized nano-chitosan supplementation in the milk is an effective way to increase the vitamin $\mathrm{C}$ supplement along with chitosan. Similarly, Park et al. (2007) also reported that nanocalcium supplementation in the milk may be an effective way to increase the bone calcium metabolism for ovarirectomised rats. Functional milk has huge demand in the market with the enhanced health beneficial properties. Therefore over the years, a huge variety of food ingredients were studied, such as L-ascorbic acid (Lee et al., 2004), isoflavone (Jeon et al., 2005), and fish oil (Fomolla et al., 2009) have been used in milk to improve the functional properties.

Nowadays consumers are more health conscious than ever. To meet the growing demand for the food with 
health promoting functions, functional milk can be developed using the appropriate nutraceutical ingredients, such as nanaopowdered peanut sprout. However, there are no informations on developing the functional milk which incorporates the nanopowdered peanut sprout. Therefore, the objective of the present study was to evaluate the physicochemical and sensory properties of the nanopowdered peanut sprout-supplemented milk during storage.

\section{Materials and Methods}

\section{Materials}

Commercial peanut sprout was offered from Jangsuche. Co., Ltd. (Korea). Peanut sprouts were ground to nanopowdered peanut sprout (NPPS) by the dry milling method at room temperature in Apexcel Co. (Korea). Market milk (3.8\% milk fat) was purchased from Seoul Dairy Co-op. (Korea). 2-thiobarbituric acid (TBA), 2, 2-diphenyl-1-pitryl-hydrazyl were obtained from Sigma Chemical Co. (USA). All chemicals were purchased from Sigma Chemical Co. (USA), and all solvents were of chromatographic grade.

\section{Solubilization of nanopowdered peanut sprouts}

To solubilise the NPPS, $0.5 \%$ (w/v) NPPS was sonicated in water for $1 \mathrm{~h}$. The NPPS solution was stirred at $800 \mathrm{rpm}$ at room temperature for $2 \mathrm{~h}$ and then $10 \%(\mathrm{w} / \mathrm{v})$ polyglycerol monostearate (PGMS) was added to be $0.2 \%(\mathrm{v} / \mathrm{v})$ solution. The resulting suspension was placed at room temperature for $24 \mathrm{~h}$, followed by the centrifugation at 3,889 $\mathrm{g}$ for $5 \mathrm{~min}$ using a centrifuge (HMR-220IV, Korea). After centrifuging, the supernatant was collected and neutralized to $\mathrm{pH} 6.6$ with $0.1 \mathrm{M} \mathrm{NaOH}$.

\section{Manufacture of NPPS enriched milk}

Different concentrations $(1,3,5,7$ and $9 \%, v / v)$ of the NPPS solution were aseptically added with pasteurized milk and agitated for $2 \mathrm{~min}$. The NPPS supplemented milk pack was then stored at $4^{\circ} \mathrm{C}$ for $0,4,8,12$ and $16 \mathrm{~d}$ for various analyses. The samples were made in duplicate.

\section{Particle size analysis and scanning electron micros- copy}

Scanning electron microscope (SEM, Hitachi S-4700, Japan) was used to analyze the microstructure of the powdered peanut spout and NPPS. The morphology of powdered peanut sprout and NPPS was in the range 50 to 150 $\mu \mathrm{m}$ by SEM and 300 to $350 \mathrm{~nm}$ by particle size analyzer (Ahn et al., 2012).

\section{pH}

The $\mathrm{pH}$ values of the NPPS enriched milk samples were measured using a glass electrode $\mathrm{pH}$ meter (Orion 900A, USA).

\section{DPPH radical scavenging activity}

The free radical scavenging activities of NPPS were measured by the 2,2-diphenyl-1-picryl-hydrazil (DPPH) method proposed by Brand-Williams et al. (1995). Briefly, $0.1 \mathrm{mM}$ solution of DPPH in ethanol was prepared and $1.0 \mathrm{~mL}$ of this solution was added to $0.5 \mathrm{~mL}$ of samples in different concentrations. After $20 \mathrm{~min}$, the absorbance was measured at $525 \mathrm{~nm}$. The DPPH radical scavenging activity was calculated according to the following equation:

\section{DPPH radical scavenging activity (\%)}

$$
=\left[\left(\mathrm{A}_{0}-\mathrm{A}_{1}\right) / \mathrm{A}_{0}\right] \times 100
$$

where $A_{0}$ was the absorbance of the control and $A_{1}$ the absorbance in the presence of the test compound.

\section{Thiobarbituric acid reactive substance (TBARS)}

TBARS of NPPS supplemented milk was performed according to the method of Stapelfeldt et al. (1997). First of all, TBA solution was made by dissolving 2-thiobarbituric acid $(1.4 \mathrm{~g})$ in $95 \%$ ethanol to $100 \mathrm{~mL}$. NPPS-supplemented milk $(17.6 \mathrm{~mL})$ was taken into a flask fitted with glass stopper, heated to $30^{\circ} \mathrm{C}$, added $1 \mathrm{~mL}$ trichloroacetic acid (TCA) solution containing $1 \mathrm{~g} / \mathrm{mL}$, followed by $95 \%$ ethanol $(2 \mathrm{~mL})$, stopped and shaked for $10 \mathrm{~s}$. After $5 \mathrm{~min}$, the contents were filtered through Whatman No. 42 . One $\mathrm{mL}$ of the TBA solution was added into $4 \mathrm{~mL}$ of the clear filtrate. The contents were mixed and placed in the water bath at $60^{\circ} \mathrm{C}$ for $1 \mathrm{~h}$ followed by cooling in an ice bath for $10 \mathrm{~min}$. Absorbance was read at $450 \mathrm{~nm}$ with a UV-VIS-NIR scanning spectrophotometer (Beckman coulter, USA). Each sample was measured at least three times.

\section{Color measurement}

Color values of milk sample supplemented with NPPS were measured using a colorimeter (CR210, Minolta, Japan) after calibrating its original value with a standard plate $(X=97.83, Y=81.58, Z=91.51)$. Measured $L^{*}, a^{*}$ and $b^{*}$ values were used as indicators of lightness, redness and yellowness, respectively.

\section{Sensory analysis}

The sensory evaluation was performed by 8 trained 
panelists, who were the graduate students ( 4 males and 4 females) in the Dairy Products Laboratory (Food Science and Technology Department, Sejong University, Seoul, Korea), aged 25 to $33 \mathrm{yr}$, and familiar with milk consumption. Panelists were trained in 2 sessions using a 7point scale, where 1 represented very weak peanut flavor, yellow color, and taste, and 7 represented very strong peanut flavor, yellow color, and taste. Reference samples prepared at the level of 1, 5, and 9\% NPPS-enriched milk were kept in a closed cup for $0,4,8,12$, and $16 \mathrm{~d}$, representing the score of 1,4 , and 7 , respectively. To test the flavor of samples, the panelists were asked to open the closed cup and sniff the headspace above the samples. The samples were then scored.

\section{Statistical analysis}

All statistical analyses were performed using SAS version 9.0 (SAS Institute, 2002). An ANOVA was performed using the general linear models procedure to determine significant differences among the samples. Means were compared by using Duncan's multiple range test $(p<0.05)$.

\section{Results and Discussion}

\section{pH}

The changes in $\mathrm{pH}$ values of milk samples supplemented with various concentrations of NPPS and control (without supplement of NPPS) during $16 \mathrm{~d}$ of storage at $4^{\circ} \mathrm{C}$ are shown in Fig. 1. The $\mathrm{pH}$ values of the milk samples ranged from 6.5 to 6.7 as a reflective of the fresh state (Seo et al., 2011). It was observed in this study pH

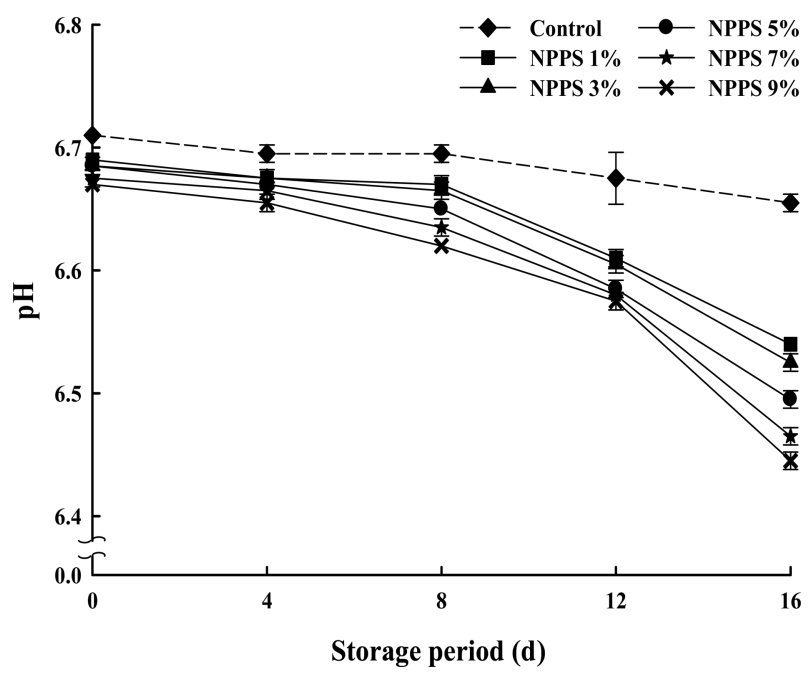

Fig. 1. Changes in $\mathrm{pH}$ of dispersable nanopowdered peanut sprout-supplemented milk stored at $4^{\circ} \mathrm{C}$ for $16 \mathrm{~d}$. NPPS: nanopowdered peanut sprout. values for all the milk samples were nearly constant during $8 \mathrm{~d}$ storage. The $\mathrm{pH}$ values for the control were slightly higher than those for all the NPPS milks. Initially $\mathrm{pH}$ values were proportionally decreased with increasing concentrations $(1,3,5,7$, and $9 \%)$ of the NPPS and this trend kept with final period of storage ranged from 6.70 to 6.42 which are in normal scope of market milk. The decrease in $\mathrm{pH}$ values resulted from the adjustment of $\mathrm{pH}$ of the NPPS solution with $0.1 \mathrm{M} \mathrm{NaOH}$ at the final stage of solubilization. The $\mathrm{pH}$ values for all the milk samples were nearly constant during $16 \mathrm{~d}$ storage and ranged from 6.5 to 6.7, as a reflective of fresh state (Lee et al., 2006). These results indicated that the various concentrations of NPPS supplement did not provide adverse effect on the $\mathrm{pH}$ of the milk during the storage of $16 \mathrm{~d}$.

\section{DPPH radical scavenging activity}

The DPPH radical scavenging activity of NPPS-supplemented milk during storage at $4^{\circ} \mathrm{C}$ for $16 \mathrm{~d}$ is shown in Fig. 2. The radical scavenging activities were normally used to measure the capacity of antioxidant activity in various plant and animal foods (Kang et al., 2010). DPPH radical scavenging activity was found to be lower in the control (without supplement of NPPS). However, increasing the concentrations of NPPS $(1,3,5,7$, and 9\%) significantly increases the DPPH radical scavenging activity in NPPS-supplemented milk $(p<0.05)$. Higher the concentration of NPPS supplementation in milk (7 and 9\%) was found to be higher radical scavenging activity at $0 \mathrm{~d}$ to $16 \mathrm{~d}$ storage of milk. NPPS are rich in resveratrol and other plant polyphenolics which has greater antioxidant activity (Kang et al., 2010). Further DPPH radical scavenging activity found to be constant upto $4 \mathrm{~d}$ and dramat-

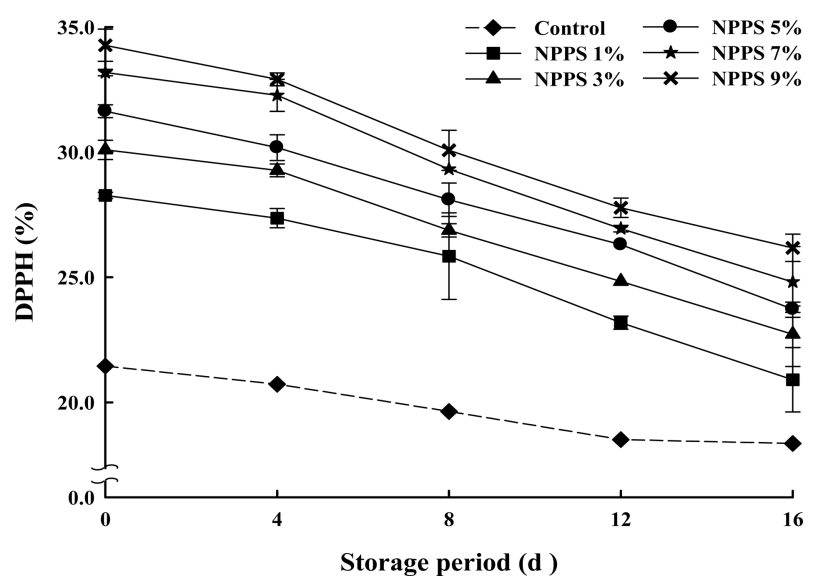

Fig. 2. Changes in DPPH of dispersable nanopowdered peanut sprout-supplemented milk stored at $4^{\circ} \mathrm{C}$ for $16 \mathrm{~d}$. NPPS: nanopowdered peanut sprout. 
ically decreased during $8 \mathrm{~d}$ to $16 \mathrm{~d}$ storage (Kang et al., 2010). However, the antioxidant activity was found to be greater in NPPS supplemented milks irrespective of its concentrations supplemented in milk. These results confirmed that NPPS provides greater antioxidant activity with increasing NPPS supplementation in milk.

\section{Changes in TBARS}

The changes in TBARS of NPPS-supplemented milk during storage at $4^{\circ} \mathrm{C}$ for $16 \mathrm{~d}$ are shown in Fig. 3. TBARS absorbance values of all samples ranged below 0.2 showed mostly lower oxidation in the milk. Increasing the concentrations of NPPS $(1,3,5,7$, and 9\%) significantly increased the TBARS values of NPPS-supplemented milk $(p<0.05)$. This was most likely due to the higher fat content in the nanopeanut sprouts which was readily prone to oxidation during the increase storage period of $16 \mathrm{~d}$. However, it did not exceed 0.2 until $16 \mathrm{~d}$ storage and were maintained the lower value of 0.15 and 0.17 up to $16 \mathrm{~d}$. Ahn et al. (2010) were also reported that milk supplemented with $I$. obliquus extract powder had lower TBARS value of 0.13 . At higher concentration of NPPS supplementation (7 and $9 \%$ ), the TBARS value exceed to 0.16 during $16 \mathrm{~d}$ storage period. It was most likely due to the higher nanopeanut sprout fat oxidation during the storage period of $16 \mathrm{~d}$. However, TBARS values were maintained within 0.16 during for 7 and $9 \%$ NPPS-sup-

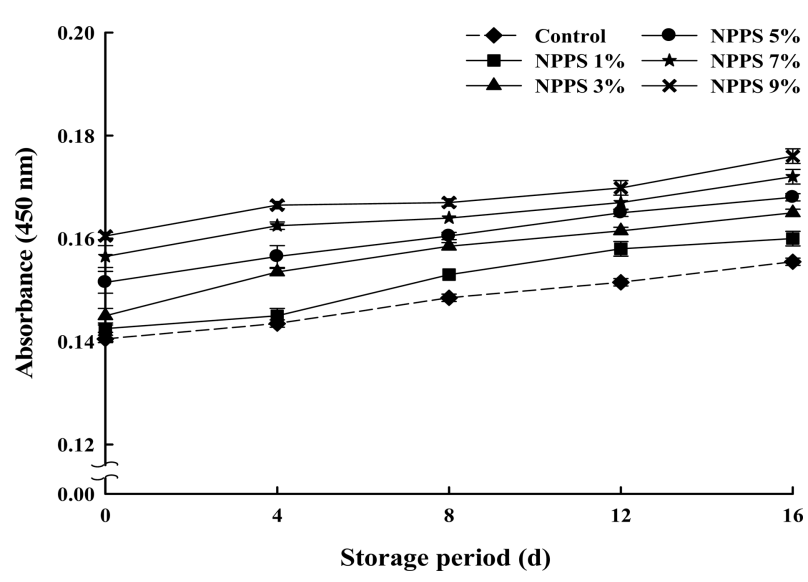

Fig. 3. Changes in thiobarbituric aicd (TBARS) values of dispersable nanopowdered peanut sprout-supplemented milk stored at $4^{\circ} \mathrm{C}$ for $16 \mathrm{~d}$. NPPS: nanopowdered peanut sprout.

plement milk during the storage of $8 \mathrm{~d}$ of the normal shelf life of market milk. Therefore, the results indicated that there was no considerable chemical oxidation in the NPPS-supplemented milk samples at various concentrations during the $16 \mathrm{~d}$ storage.

\section{Color}

The changes in color of NPPS-supplemented milk samples stored at $4^{\circ} \mathrm{C}$ for $16 \mathrm{~d}$ are presented in Table 1 . The $\mathrm{L}^{*}$ values of the milk supplemented with different concentrations of NPPS were not significantly differ at

Table 1. Changes in color of dispersable nanopowdered peanut sprout-supplemented milk stored at $4^{\circ} \mathrm{C}$ for $16 \mathrm{~d}$

\begin{tabular}{|c|c|c|c|c|c|c|}
\hline \multirow{2}{*}{ Color } & \multirow{2}{*}{ Conc. $(\%)$} & \multicolumn{5}{|c|}{ Storage period (d) } \\
\hline & & 0 & 4 & 8 & 12 & 16 \\
\hline \multirow{6}{*}{$\begin{array}{c}\mathrm{L}^{*} \\
\text { (lightness) }\end{array}$} & Control & $89.01 \pm 0.24^{1 \mathrm{aA} 2)}$ & $89.03 \pm 0.25^{\mathrm{aA}}$ & $89.11 \pm 0.24^{\mathrm{aA}}$ & $89.08 \pm 0.32^{\mathrm{aA}}$ & $89.01 \pm 0.07^{\mathrm{aA}}$ \\
\hline & 1 & $89.03 \pm 0.25^{\mathrm{aA}}$ & $89.02 \pm 0.22^{\mathrm{aA}}$ & $89.07 \pm 0.20^{\mathrm{aA}}$ & $89.06 \pm 0.20^{\mathrm{aA}}$ & $89.10 \pm 0.08^{\mathrm{aA}}$ \\
\hline & 3 & $89.14 \pm 0.12^{\mathrm{aA}}$ & $89.09 \pm 0.42^{\mathrm{aA}}$ & $88.98 \pm 0.17^{\mathrm{aA}}$ & $89.02 \pm 0.23^{\mathrm{aA}}$ & $89.04 \pm 0.23^{\mathrm{aA}}$ \\
\hline & 5 & $89.11 \pm 0.20^{\mathrm{aA}}$ & $89.04 \pm 0.21^{\mathrm{aA}}$ & $89.04 \pm 0.21^{\mathrm{aA}}$ & $89.06 \pm 0.16^{\mathrm{aA}}$ & $89.04 \pm 0.15^{\mathrm{aA}}$ \\
\hline & 7 & $89.07 \pm 0.11^{\mathrm{aA}}$ & $88.94 \pm 0.22^{\mathrm{aA}}$ & $89.06 \pm 0.16^{\mathrm{aA}}$ & $88.95 \pm 0.13^{\mathrm{aA}}$ & $88.97 \pm 0.19^{\mathrm{aA}}$ \\
\hline & 9 & $89.14 \pm 0.11^{\mathrm{aA}}$ & $88.97 \pm 0.12^{\mathrm{aB}}$ & $89.03 \pm 0.09^{\mathrm{aB}}$ & $89.00 \pm 0.10^{\mathrm{aB}}$ & $89.07 \pm 0.12^{\mathrm{aAB}}$ \\
\hline \multirow{6}{*}{$\begin{array}{c}\mathrm{a}^{*} \\
\text { (redness) }\end{array}$} & Control & $2.72 \pm 0.09^{\mathrm{cB}}$ & $2.65 \pm 0.16^{\mathrm{bB}}$ & $2.61 \pm 0.11^{\mathrm{bB}}$ & $2.75 \pm 0.28^{\mathrm{bB}}$ & $2.96 \pm 0.04^{\mathrm{cA}}$ \\
\hline & 1 & $2.77 \pm 0.06^{\mathrm{bcC}}$ & $2.65 \pm 0.12^{\mathrm{bD}}$ & $2.61 \pm 0.11^{\mathrm{bD}}$ & $2.86 \pm 0.09^{\mathrm{abB}}$ & $2.97 \pm 0.05^{\mathrm{cA}}$ \\
\hline & 3 & $2.83 \pm 0.06^{\mathrm{abBC}}$ & $2.77 \pm 0.16^{\mathrm{aC}}$ & $2.91 \pm 0.09^{\mathrm{aB}}$ & $2.84 \pm 0.17^{\mathrm{abBC}}$ & $3.04 \pm 0.09^{\mathrm{bA}}$ \\
\hline & 5 & $2.84 \pm 0.09^{\mathrm{abBC}}$ & $2.78 \pm 0.10^{\mathrm{aC}}$ & $2.87 \pm 0.10^{\mathrm{aB}}$ & $2.85 \pm 0.07^{\mathrm{abBC}}$ & $3.07 \pm 0.06^{\mathrm{bA}}$ \\
\hline & 7 & $2.87 \pm 0.07^{\mathrm{aB}}$ & $2.79 \pm 0.10^{\mathrm{aB}}$ & $2.86 \pm 0.16^{\mathrm{aB}}$ & $2.90 \pm 0.11^{\mathrm{aB}}$ & $3.04 \pm 0.07^{\mathrm{bA}}$ \\
\hline & 9 & $2.89 \pm 0.14^{\mathrm{aC}}$ & $2.82 \pm 0.11^{\mathrm{aC}}$ & $2.90 \pm 0.05^{\mathrm{aBC}}$ & $2.97 \pm 0.06^{\mathrm{aB}}$ & $3.14 \pm 0.04^{\mathrm{sA}}$ \\
\hline \multirow{6}{*}{$\begin{array}{c}\mathrm{b}^{*} \\
\text { (yellowness) }\end{array}$} & Control & $2.76 \pm 0.22^{\mathrm{dC}}$ & $2.86 \pm 0.25^{\mathrm{bC}}$ & $3.14 \pm 0.26^{\mathrm{cB}}$ & $3.89 \pm 0.44^{\mathrm{abcA}}$ & $3.80 \pm 0.08^{\mathrm{cA}}$ \\
\hline & 1 & $3.25 \pm 0.21^{\mathrm{cB}}$ & $3.31 \pm 0.29^{\mathrm{aB}}$ & $3.21 \pm 0.31^{\mathrm{cB}}$ & $3.89 \pm 0.22^{\mathrm{abcA}}$ & $4.07 \pm 0.16^{\mathrm{bA}}$ \\
\hline & 3 & $3.63 \pm 0.16^{\mathrm{bBC}}$ & $3.40 \pm 0.46^{\mathrm{aC}}$ & $3.85 \pm 0.23^{\mathrm{bAB}}$ & $3.84 \pm 0.44^{\mathrm{bcAB}}$ & $4.14 \pm 0.27^{\mathrm{bA}}$ \\
\hline & 5 & $3.62 \pm 0.31^{\mathrm{bC}}$ & $3.52 \pm 0.27^{\mathrm{aC}}$ & $3.93 \pm 0.27^{\mathrm{bB}}$ & $3.63 \pm 0.24^{\mathrm{cC}}$ & $4.25 \pm 0.21^{\mathrm{bA}}$ \\
\hline & 7 & $3.73 \pm 0.18^{\mathrm{abB}}$ & $3.32 \pm 0.25^{\mathrm{aC}}$ & $4.16 \pm 0.26^{\mathrm{aA}}$ & $3.98 \pm 0.24^{\mathrm{abA}}$ & $4.15 \pm 0.28^{\mathrm{bA}}$ \\
\hline & 9 & $3.87 \pm 0.16^{\mathrm{aC}}$ & $3.59 \pm 0.23^{\mathrm{aD}}$ & $4.16 \pm 0.14^{\mathrm{aB}}$ & $4.15 \pm 0.15^{\mathrm{aB}}$ & $4.48 \pm 0.15^{\mathrm{aA}}$ \\
\hline
\end{tabular}

\footnotetext{
${ }^{1)} \operatorname{Mean} \pm \operatorname{SD}(\mathrm{n}=10)$
}

${ }^{2)}$ Values with different superscript in a same row (A-D) and in a same column (a-c) are significant at $p<0.05$ by Duncan's multiple range test

${ }^{3)}$ NPPS: nanopowdered peanut sprouts 
increasing storage of $16 \mathrm{~d}(p>0.05)$. According to Philips et al. (1995), the $L^{*}$ value of milk has been demonstrated to have the most positive impact on consumer appeal. Therefore, in this study, it is speculated that the supplementation of the NPPS in milk samples would not influence the consumer appeal over the extended storage of 16 d. Increasing the concentrations of NPPS-supplementation in milk at $0 \mathrm{~d}$ markedly increase the $\mathrm{b}^{*}$ values, most likely due to the light yellow color of NPPS. Similarly Seo et al. (2011) also reported that the addition of nanopowdered chitosan in milk greatly increases the $b^{*}$ values during the increase storage period due to the light yellow color of the nanochitosan. Increasing the storage period to $16 \mathrm{~d}$ greatly increased the $\mathrm{a}^{*}$ and $\mathrm{b}^{*}$ values irrespective of treatments (Table 1). However, $\mathrm{a}^{*}$ value was found to be not significantly different at $1 \%$ NPPS supplementation during the storage period from 0 to $16 \mathrm{~d}$ of storage $(p>0.05)$. Therefore, the results indicated that there were no considerable changes in $L^{*}$ values of the NPPS-supplemented milk samples at various concentrations during the $16 \mathrm{~d}$ storage.

Table 2. Sensory characteristics of dispersable nanopowdered peanut sprout-supplemented milk stored at $4^{\circ} \mathrm{C}$ for $16 \mathrm{~d}$

\begin{tabular}{|c|c|c|c|c|c|c|c|c|}
\hline \multirow{2}{*}{$\begin{array}{l}\text { Concentration of } \\
\text { sample }(\%, w / v)\end{array}$} & \multirow{2}{*}{$\frac{\text { Appearance }}{\text { Color }}$} & \multicolumn{3}{|c|}{ Flavor } & \multicolumn{3}{|c|}{ Taste } & \multirow{2}{*}{$\begin{array}{c}\text { Overall } \\
\text { acceptability }\end{array}$} \\
\hline & & Peanut & Beany & Cooked & Astringency & Bitterness & Sweetness & \\
\hline \multicolumn{9}{|c|}{$0 \mathrm{~d}$} \\
\hline Control & $1.00 \pm 0.00^{1) \mathrm{aA} 2)}$ & $1.00 \pm 0.00^{\mathrm{bA}}$ & $1.00 \pm 0.00^{\mathrm{dA}}$ & $4.00 \pm 0.00^{\mathrm{aA}}$ & $1.00 \pm 0.00^{\mathrm{aA}}$ & $1.00 \pm 0.00^{\mathrm{aA}}$ & $4.00 \pm 0.00^{\mathrm{abA}}$ & $4.40 \pm 0.97^{\mathrm{bA}}$ \\
\hline 1 & $1.10 \pm 0.32^{\mathrm{Aa}}$ & $1.70 \pm 0.67^{\mathrm{bA}}$ & $1.70 \pm 0.67^{\mathrm{cAB}}$ & $4.10 \pm 0.32^{\mathrm{aA}}$ & $1.10 \pm 0.32^{\mathrm{aB}}$ & $1.00 \pm 0.00^{\mathrm{aA}}$ & $3.90 \pm 0.32^{\mathrm{abA}}$ & $5.30 \pm 0.82^{\mathrm{aA}}$ \\
\hline 3 & $1.10 \pm 0.32^{\mathrm{aA}}$ & $2.70 \pm 0.95^{\mathrm{aA}}$ & $2.00 \pm 0.67^{\mathrm{bcA}}$ & $3.70 \pm 0.67^{\mathrm{aC}}$ & $1.10 \pm 0.32^{\mathrm{aB}}$ & $1.00 \pm 0.00^{\mathrm{aB}}$ & $4.10 \pm 0.074^{\mathrm{aA}}$ & $5.40 \pm 0.52^{\mathrm{aA}}$ \\
\hline 5 & $1.10 \pm 0.32^{\mathrm{aA}}$ & $3.20 \pm 1.14^{\mathrm{aA}}$ & $2.10 \pm 0.88^{\mathrm{bcB}}$ & $3.60 \pm 0.70^{\mathrm{aAB}}$ & $1.10 \pm 0.32^{\mathrm{aB}}$ & $1.00 \pm 0.00^{\mathrm{aB}}$ & $4.10 \pm 0.74^{\mathrm{aA}}$ & $4.80 \pm 0.42^{\mathrm{abA}}$ \\
\hline 7 & $1.10 \pm 0.32^{\mathrm{aA}}$ & $3.00 \pm 1.15^{\mathrm{aA}}$ & $2.50 \pm 0.97^{\mathrm{bB}}$ & $3.80 \pm 1.03^{\mathrm{aA}}$ & $1.10 \pm 0.32^{\mathrm{aB}}$ & $1.10 \pm 0.32^{\mathrm{aB}}$ & $4.00 \pm 0.47^{\mathrm{abA}}$ & $4.70 \pm 0.82^{\mathrm{abA}}$ \\
\hline 9 & $1.10 \pm 0.32^{\mathrm{aA}}$ & $3.60 \pm 1.43^{\mathrm{aA}}$ & $3.20 \pm 0.92^{\mathrm{aA}}$ & $3.40 \pm 1.43^{\mathrm{aAB}}$ & $1.30 \pm 0.67^{\mathrm{aB}}$ & $1.10 \pm 0.32^{\mathrm{aC}}$ & $3.50 \pm 0.71^{\mathrm{bA}}$ & $3.70 \pm 0.95^{\mathrm{cA}}$ \\
\hline \multicolumn{9}{|c|}{$4 d$} \\
\hline Control & $1.00 \pm 0.00^{\mathrm{aA}}$ & $1.00 \pm 0.00^{\mathrm{bA}}$ & $1.00 \pm 0.00^{\mathrm{cA}}$ & $4.00 \pm 0.00^{\mathrm{aA}}$ & $1.00 \pm 0.00^{\mathrm{bA}}$ & $1.00 \pm 0.00^{\mathrm{bA}}$ & $4.00 \pm 0.00^{\mathrm{abA}}$ & $4.70 \pm 0.95^{\mathrm{abA}}$ \\
\hline 1 & $1.00 \pm 0.00^{\mathrm{aA}}$ & $1.80 \pm 0.42^{\mathrm{bA}}$ & $1.10 \pm 0.32^{\mathrm{cB}}$ & $4.10 \pm 0.32^{\mathrm{aA}}$ & $1.00 \pm 0.00^{\mathrm{bB}}$ & $1.00 \pm 0.00^{\mathrm{bA}}$ & $4.00 \pm 0.00^{\mathrm{abA}}$ & $5.40 \pm 0.84^{\mathrm{aA}}$ \\
\hline 3 & $1.00 \pm 0.00^{\mathrm{aA}}$ & $3.20 \pm 0.92^{\mathrm{aA}}$ & $1.80 \pm 0.92^{\mathrm{bcA}}$ & $4.00 \pm 0.82^{\mathrm{aABC}}$ & $1.00 \pm 0.00^{\mathrm{bB}}$ & $1.00 \pm 0.00^{\mathrm{bB}}$ & $4.10 \pm 0.57^{\mathrm{aA}}$ & $5.20 \pm 0.92^{\mathrm{aA}}$ \\
\hline 5 & $1.10 \pm 0.32^{\mathrm{aA}}$ & $3.90 \pm 1.45^{\mathrm{aA}}$ & $2.50 \pm 1.27^{\mathrm{bB}}$ & $3.70 \pm 0.95^{\mathrm{abAB}}$ & $1.50 \pm 0.53^{\mathrm{abAB}}$ & $1.00 \pm 0.00^{\mathrm{bB}}$ & $3.60 \pm 0.52^{\mathrm{abA}}$ & $4.50 \pm 0.71^{\mathrm{abA}}$ \\
\hline 7 & $1.10 \pm 0.32^{\mathrm{aA}}$ & $4.00 \pm 1.41^{\mathrm{aA}}$ & $2.60 \pm 1.26^{\mathrm{bB}}$ & $3.40 \pm 0.70^{\mathrm{abA}}$ & $1.60 \pm 0.97^{\mathrm{abB}}$ & $1.40 \pm 0.84^{\mathrm{abB}}$ & $3.50 \pm 0.71^{\mathrm{bA}}$ & $3.90 \pm 1.10^{\mathrm{bcAB}}$ \\
\hline 9 & $1.10 \pm 0.32^{\mathrm{aA}}$ & $4.30 \pm 1.83^{\mathrm{aA}}$ & $3.90 \pm 1.91^{\mathrm{aA}}$ & $3.20 \pm 1.14^{\mathrm{bAB}}$ & $2.00 \pm 1.15^{\mathrm{aAB}}$ & $1.80 \pm 0.79^{\mathrm{aAB}}$ & $3.60 \pm 0.84^{\mathrm{abA}}$ & $3.30 \pm 1.06^{\mathrm{cA}}$ \\
\hline \multicolumn{9}{|c|}{$8 \mathrm{~d}$} \\
\hline Control & $1.00 \pm 0.00^{\mathrm{aA}}$ & $1.00 \pm 0.00^{\mathrm{dA}}$ & $1.00 \pm 0.00^{\mathrm{dA}}$ & $4.00 \pm 0.00^{\mathrm{aA}}$ & $1.00 \pm 0.00^{\mathrm{aA}}$ & $1.00 \pm 0.00^{\mathrm{aA}}$ & $4.00 \pm 0.00^{\mathrm{aA}}$ & $4.90 \pm 0.88^{\mathrm{abA}}$ \\
\hline 1 & $1.00 \pm 0.00^{\mathrm{aA}}$ & $1.70 \pm 0.67^{\mathrm{cdA}}$ & $1.30 \pm 0.48^{\mathrm{cdB}}$ & $4.10 \pm 0.32^{\mathrm{aA}}$ & $1.10 \pm 0.32^{\mathrm{aB}}$ & $1.00 \pm 0.00^{\mathrm{aA}}$ & $4.10 \pm 0.32^{\mathrm{aA}}$ & $5.30 \pm 0.82^{\mathrm{aA}}$ \\
\hline 3 & $1.00 \pm 0.00^{\mathrm{aA}}$ & $2.60 \pm 0.84^{\mathrm{bcA}}$ & $2.10 \pm 0.74^{\mathrm{bcA}}$ & $4.20 \pm 0.42^{\mathrm{aAB}}$ & $1.10 \pm 0.32^{\mathrm{aB}}$ & $1.10 \pm 0.32^{\mathrm{aB}}$ & $4.10 \pm 0.32^{\mathrm{aA}}$ & $5.10 \pm 0.57^{\mathrm{aA}}$ \\
\hline 5 & $1.10 \pm 0.32^{\mathrm{aA}}$ & $3.40 \pm 0.84^{\mathrm{abA}}$ & $2.80 \pm 1.23^{\mathrm{bAB}}$ & $3.70 \pm 0.67^{\mathrm{aAB}}$ & $1.30 \pm 0.67^{\mathrm{aB}}$ & $1.00 \pm 0.00^{\mathrm{aB}}$ & $3.80 \pm 0.42^{\mathrm{abA}}$ & $4.40 \pm 0.52^{\mathrm{bA}}$ \\
\hline 7 & $1.10 \pm 0.32^{\mathrm{aA}}$ & $3.60 \pm 1.35^{\mathrm{abA}}$ & $4.00 \pm 1.15^{\mathrm{aA}}$ & $3.70 \pm 0.67^{\mathrm{aA}}$ & $1.20 \pm 0.63^{\mathrm{aB}}$ & $1.20 \pm 0.42^{\mathrm{aB}}$ & $3.90 \pm 0.74^{\mathrm{abA}}$ & $3.60 \pm 0.52^{\mathrm{cB}}$ \\
\hline 9 & $1.10 \pm 0.32^{\mathrm{aA}}$ & $3.80 \pm 1.75^{\mathrm{aA}}$ & $4.20 \pm 1.14^{\mathrm{aA}}$ & $3.70 \pm 0.67^{\mathrm{aAB}}$ & $1.40 \pm 0.70^{\mathrm{aB}}$ & $1.20 \pm 0.42^{\mathrm{aBC}}$ & $3.50 \pm 0.71^{\mathrm{bA}}$ & $3.40 \pm 0.52^{\mathrm{cA}}$ \\
\hline \multicolumn{9}{|c|}{$12 \mathrm{~d}$} \\
\hline Control & $1.00 \pm 0.00^{\mathrm{aA}}$ & $1.00 \pm 0.00^{\mathrm{cA}}$ & $1.00 \pm 0.00^{\mathrm{cA}}$ & $4.00 \pm 0$. & $1.00 \pm 0.00^{\mathrm{bA}}$ & $1.00 \pm 0.00^{\mathrm{aA}}$ & $4.00 \pm 0.00^{\mathrm{aA}}$ & $4.80 \pm 0.92^{\mathrm{aA}}$ \\
\hline 1 & $1.00 \pm 0.0^{\mathrm{aA}}$ & $2.10 \pm 1.37^{\mathrm{bcA}}$ & $1.80 \pm 0.79^{\mathrm{bcAB}}$ & $4.40 \pm 0.52^{\mathrm{aA}}$ & $1.20 \pm 0.63^{\mathrm{abAB}}$ & $1.20 \pm 0.42^{\mathrm{aA}}$ & $4.00 \pm 0.00^{\mathrm{aA}}$ & $4.70 \pm 1.37^{\mathrm{aA}}$ \\
\hline 3 & $1.00 \pm 0.00^{\mathrm{aA}}$ & $3.30 \pm 1.83^{\mathrm{abA}}$ & $2.50 \pm 1.27^{\mathrm{abA}}$ & $4.40 \pm 0.52^{\mathrm{aA}}$ & $1.30 \pm 0.48^{\mathrm{abB}}$ & $1.20 \pm 0.42^{\mathrm{aAB}}$ & $3.90 \pm 0.32^{\mathrm{aAB}}$ & $4.20 \pm 1.14^{\mathrm{abB}}$ \\
\hline 5 & $1.00 \pm 0.00^{\mathrm{aA}}$ & $3.60 \pm 1.43^{\mathrm{aA}}$ & $2.50 \pm 1.18^{\mathrm{abB}}$ & $4.20 \pm 0.42^{\mathrm{aA}}$ & $1.70 \pm 0.67^{\mathrm{aAB}}$ & $1.20 \pm 0.42^{\mathrm{aB}}$ & $4.10 \pm 0.57^{\mathrm{aA}}$ & $3.50 \pm 0.97^{\mathrm{bB}}$ \\
\hline 7 & $1.00 \pm 0.00^{\mathrm{aA}}$ & $3.40 \pm 0.71^{\mathrm{abA}}$ & $2.60 \pm 1.17^{\mathrm{abB}}$ & $3.90 \pm 0.74^{\mathrm{aA}}$ & $1.40 \pm 0.52^{\mathrm{abB}}$ & $1.00 \pm 0.00^{\mathrm{aB}}$ & $3.80 \pm 0.42^{\mathrm{aA}}$ & $3.70 \pm 1.16^{\mathrm{bB}}$ \\
\hline 9 & $1.10 \pm 0.32^{\mathrm{aA}}$ & $4.10 \pm 1.45^{\mathrm{aA}}$ & $3.40 \pm 1.17^{\mathrm{aA}}$ & $4.00 \pm 0.67^{\mathrm{aA}}$ & $1.40 \pm 0.52^{\mathrm{abB}}$ & $1.20 \pm 0.42^{\mathrm{aBC}}$ & $3.90 \pm 0.74^{\mathrm{aA}}$ & $3.50 \pm 1.18^{\mathrm{bA}}$ \\
\hline \multicolumn{9}{|c|}{$16 \mathrm{~d}$} \\
\hline Control & $1.00 \pm 0.00^{\mathrm{aA}}$ & $1.00 \pm 0.00^{\mathrm{dA}}$ & $1.00 \pm 0.00^{\mathrm{cA}}$ & $4.00 \pm 0.00^{\mathrm{aA}}$ & $1.00 \pm 0.00^{\mathrm{bA}}$ & $1.00 \pm 0.00^{\mathrm{bA}}$ & $4.00 \pm 0.00^{\mathrm{aA}}$ & $5.10 \pm 0.99^{\mathrm{aA}}$ \\
\hline 1 & $1.00 \pm 0.00^{\mathrm{aA}}$ & $2.00 \pm 1.15^{\mathrm{cdA}}$ & $2.40 \pm 2.01^{\mathrm{bcA}}$ & $3.40 \pm 0.97^{\mathrm{abB}}$ & $1.70 \pm 1.06^{\mathrm{abA}}$ & $1.30 \pm 0.67^{\mathrm{abA}}$ & $3.50 \pm 0.85^{\mathrm{aB}}$ & $3.30 \pm 1.70^{\mathrm{bB}}$ \\
\hline 3 & $1.00 \pm 0.00^{\mathrm{aA}}$ & $2.90 \pm 1.10^{\mathrm{bcA}}$ & $3.10 \pm 2.38^{\mathrm{abA}}$ & $3.40 \pm 0.97^{\mathrm{abC}}$ & $2.10 \pm 1.37^{\mathrm{abA}}$ & $1.50 \pm 0.71^{\mathrm{abA}}$ & $3.50 \pm 0.85^{\mathrm{aB}}$ & $3.00 \pm 1.41^{\mathrm{bcC}}$ \\
\hline 5 & $1.00 \pm 0.00^{\mathrm{aA}}$ & $3.00 \pm 0.94^{\mathrm{bcA}}$ & $3.90 \pm 1.85^{\mathrm{abA}}$ & $3.30 \pm 0.95^{\mathrm{abB}}$ & $2.10 \pm 1.20^{\mathrm{abA}}$ & $1.60 \pm 0.70^{\mathrm{abA}}$ & $3.60 \pm 0.84^{\mathrm{aA}}$ & $2.60 \pm 0.97^{\mathrm{bcC}}$ \\
\hline 7 & $1.00 \pm 0.00^{\mathrm{aA}}$ & $3.40 \pm 1.51^{\mathrm{abA}}$ & $4.10 \pm 2.18^{\mathrm{abA}}$ & $3.10 \pm 1.45^{\mathrm{abA}}$ & $2.60 \pm 1.71^{\mathrm{aA}}$ & $2.10 \pm 1.37^{\mathrm{aA}}$ & $3.50 \pm 1.35^{\mathrm{aA}}$ & $2.30 \pm 0.82^{\mathrm{bcC}}$ \\
\hline 9 & $1.00 \pm 0.00^{\mathrm{aA}}$ & $4.40 \pm 1.51^{\mathrm{aA}}$ & $4.50 \pm 2.12^{\mathrm{aA}}$ & $2.80 \pm 1.32^{\mathrm{bB}}$ & $2.70 \pm 1.57^{\mathrm{aA}}$ & $2.10 \pm 1.10^{\mathrm{aA}}$ & $3.30 \pm 1.25^{\mathrm{aA}}$ & $2.00 \pm 0.47^{\mathrm{cB}}$ \\
\hline
\end{tabular}

${ }^{1)} \operatorname{Mean} \pm \operatorname{SD}(\mathrm{n}=10)$

${ }^{2)}$ Values with different superscript in a same row (A-D) and in a same column (a-c) are different significantly at $p<0.05$.

${ }^{3)}$ NPPS: nanopowdered peanut sprout 


\section{Sensory evaluation}

The sensory properties of NPPS-supplemented milk stored at $4^{\circ} \mathrm{C}$ for $16 \mathrm{~d}$ are shown in Table 2. Appearance, flavor, and taste properties were analyzed with increasing concentrations $(1,3,5,7$, and $9 \%)$ of NPPS supplementation and storage period of $16 \mathrm{~d}$. The appearance scores for the NPPS-supplemented milk at different concentrations and for the control were not significantly different by the prolonged storage period of $16 \mathrm{~d}$ or the supplementation of NPPS ( $p>0.05)$. Peanut, beany, and cooked flavor significantly increased with increased supplementation of NPPS in milk at $0 \mathrm{~d}(p<0.05)$. Further increasing the storage period from 0 to $16 \mathrm{~d}$ significantly increases the flavor properties $(p<0.05)$. Howeve: at the lower concentrations $(1,3$, and $5 \%)$ of NPPS-supplementaion, peanut, beany, and cooked flavor were quite similar to control upto $8 \mathrm{~d}$ storage. In the taste test, astringency and bitterness were found to be lower without much difference during $0 \mathrm{~d}$. Increasing the storage period of $16 \mathrm{~d}$ greatly increased the astringent and bitterness score irrespective of the concentrations of NPPS-supplemented to the milk. It was correlated to the TBARS value which undergoes greater oxidation during the increase storage period of $16 \mathrm{~d}$. Seo et al. (2011) are also reported that addition of nanochitosan in milk greatly increase the astringent score in milk during the storage periods. Sweetness scores found to be decreased with increasing supplementation of NPPS in milk at $0 \mathrm{~d}$. Increasing the storage period to $16 \mathrm{~d}$ greatly reduced the sweetness score of NPPS-supplement milk most likely due to the greater oxidation of milk. Finally, NPPS supplemented into the milk samples at lower concentrations (1 and 3\%) did not significantly influence the overall acceptability at 0,4 , and $8 \mathrm{~d}$ of storage $(p>0.05)$. Based on all the sensory data obtained from the current study, it is suggested that NPPS concentrations (1 and $3 \%$ ) could be used for the supplementation in milk without affecting the sensory properties.

This study was designed to develop the NPPS milk and to evaluate the effect of supplementing NPPS on the physicochemical and sensory properties of the products during storage. The data on $\mathrm{pH}$, color, and sensory analysis indicated that the lower concentrations (1 and 3\%) of NPPS could be applicable in the development of functional milk. The production of the milk which incorporates the NPPS can broaden the utilization of nanopeanut sprout extract, and the products can be regarded as possible health-promoting nutraceutical foods.

\section{Acknowledgements}

This study was supported by a grant from Small and Medium Business Administration in Seoul, Republic of Korea.

\section{References}

1. Ahn, Y. J., Ganesan, P., and Kwak, H. S. (2012) Comparision of nanopowdered and powdered peanut sprout-added yogurt on oits physicochemical and sensory properties during storage. Kor. J. Food Sci. An. 32: 553-560

2. Brand-Williams, W., Cuvelier, M. E., and Berset, C. (1995) Use of a free radical method to evaluate antioxidant activity. Lє bensm- Wissu- Technol. 28, 25-30.

3. Fomolla, J., Lopez-Huertas, E., Machado, F. J., Molina, D., Alvarez, I., Marmol, E., Navas, M., Palacin, E., Garcia-Valls, M. J., Remon, B., Boza, J. J., and Marti, J. L. (2009) Milk enriched with "health fatty acids" improves cardiovascular risk markers and nutritional status in human volunteers. $J$. Nutr. 25, 408-414.

4. Jeon, B. J., Kim, N. C., Han, E. M., and Kwak, H. S. (2005) Application of microencapsulated isoflavone into milk. Arch. Pharm. Res. 28, 859-865.

5. Kang, H. I., Kim, J. Y., Park, K. W., Kang, J. S., Choi, M. R., Moon, K. D., and Seo, K. I. (2010) Antioxidative effect of peanut sprout extracts. Korean J. Food Sci. Nutr. 39, 941946.

6. Lee, J. B., Ahn, J., Lee, J., and Kwak, H. S. (2004) L-ascorbic acid microencapsulated with polyacylglycerol monostearate for milk fortification. Biosci. Biotechnol. Biochem. 68, 495-500.

7. Lee, S. J., Hwang, J. H., Kim, S. H., Min, S. G., and Kwak, H. S. (2006) Comparison of the physicochemical properties of freeze-concentrated versus evaporated milk. Food Sci. Biotechnol. 15, 844-850.

8. Lyons, M. M., Yu, C., Toma, R. B., Cho, S.Y., Reiboldt, W., Lee, J., and van Breemen, R. B. (2003) Resveratrol in raw and baked blueberries and bilberries. J. Agric. Food Chem. 51, 5867-5870.

9. Park, H. S., Jeon, B. J., Ahn, J., and Kwak, H. S. (2007) Effects of nanocalcium supplemented milk on bone calcium metabolism in ovariectomized rats. Asian-Aust. J. Anim. Sci. 20, 1266-1271.

10. SAS Institute, (2002) SAS User's Guide: Statistics, Version 9.0 Cary, NC, USA.

11. Seo, M. H., Chang, Y. H., Lee, S., and Kwak, H. S. (2011) The physicochemical and sensory properties of milk supplemented with ascorbic acid-soluble nano chitosan during storage. Int. J. Dairy Technol. 64, 57-63.

12. Servili, M., Esposto, S., Fabiani, R., Urbani, S.,Taticchi, A., Mariucci, F., Selvaggini, R., and Montedoro, G. F. (2009) Phenolic compounds in olive oil: antioxidant, health and sensory activities according to their chemical structure. Inflammopharmacology 17, 1-9. 
13. Sharma, S., Anjaneyulu, M., Kulkarni, S. K., and Chopra, K. (2006) Resveratrol, a polyphenolic phytoalexin, attenuates diabetic nephropathy in rats. Pharmacol. 76, 69-75.

14. Stapelfeldt, H., Nielsen, B. R., and Skibsted, L. H. (1997) Effect of heat treatment, water activity and storage temperature on the oxidative stability of whole milk powder. Int. Dairy J. 7, 331-339.

15. Tokusoglu, O., Unal, M. K., and Yemis, F. (2005) Determi- nation of phytoalexin in peanut and pistachios by HPLCDAD and GC-MS. J. Agric. Food Chem. 53, 5003-5009.

16. Wang, Y., Catana, F., Yang, Y., Roderick, R., and van Breemen R. B. (2002) An LC-MS method for analyzing total resveratrol in grape juice, cranberry juice, and in wine. J. Agric. Food Chem. 50, 431-435.

(Received 2012.9.13/Revised 2012.11.23/Accepted 2012.12.7) 